\title{
PENGARUH KONSUMSI EKSTRAK DAUN KELOR DAN MADU TERHADAP PENINGKATAN HB IBU HAMIL DI WILAYAH KERJA PUSKESMAS WAY HALIM KOTA BANDAR LAMPUNG
}

\author{
Usastiawaty Cik Ayu Saadiah Isnainy ${ }^{1}$ Lidya Arianti ${ }^{2}$, Desti Rosalia ${ }^{3}$
}

1Dosen Prodi DIII Keperawatan Universitas Malahayati Bandar Lampung

Email :usastiawatiycasi@gmail.com

${ }^{2}$ Dosen Program Studi Ilmu Keperawatan Universitas Malahayati

Email: lidya.arianti@yahoo.co.id

${ }^{3}$ Mahasiswi keperawatan Universitas Malahayatl Bandar Lampung

E-mail : destirosaliahasando@gmail.com

\section{THE EFFECT OF CONSUMPTION OF KELOR AND HONEY LEAF EXTRACTS ON INCREASING PREGNANT WOMEN HB IN WORKING AREAS OF PUSKESMAS WAY HALIM KOTA BANDAR LAMPUNG}

Introduction:The proportion of the risk of chronic lack of energy in women of childbearing age decreased compared to 2013, from 24.2 percent in women of childbearing age who became pregnant in 2013 to 17.3 percent in 2018. In addition to women of childbearing age 20.8 percent in 2013 decreased be 14.5 percent in 2018 (Riskesdas, 2018). The percentage of pregnant women experiencing anemia increased compared to the results of Riskesdas in 2013 which amounted to 37.1 percent.

Objective: To know the effect of consumption of Moringa leaf extract and honey on the increase of $\mathrm{Hb}$ of pregnant women in the Work Area of Way Halim Health Center, Bandar Lampung City in 2019.

Method: This type of research is quantitative. The design of the Quasi Experimental method is one group pretest-posttest one group pretest-posttest approach. The sample used was 30 respondents, purposive sampling technique. Data analysis used univariate and bivariate with t-test.

Results: The average HB of pregnant women after being given extra Moringa leaves and honey in the Work Area of Way Halim Health Center, Bandar Lampung City in 2019 with Mean 11,100 Min 9.5 Max 12.2 and standard deviation of 0.5657 and standard error 0.1033 , and after being given the intervention Mean 11,100 Min 9.5 Max 12.2 and standard deviation 0.5657 and standard error 0.1033 . The statistical test results obtained $\mathrm{P}$-value $=0.000$.

Conclusion: This means that there is an effect of consumption of Moringa leaf extract and honey on increasing $\mathrm{Hb}$ of pregnant women in the Work Area of Way Halim Public Health Center, Bandar Lampung City in 2019. Advice for pregnant women to always consume Moringa leaf extract by taking capsules containing Moringa leaf powder with a dose of 2x 2 capsules / day (capsules containing 500 $\mathrm{mg}$ of Moringa leaf powder) for 15 days, for preparation before labor, because during labor the mother needs energy, and enough blood after delivery.

Keywords: Moringa Leaf Extract And Honey, Hemoglobin, Pregnant Women 
INTISARI: PENGARUH KONSUMSI EKSTRAK DAUN KELOR DAN MADU TERHADAP PENINGKATAN HB IBU HAMIL DI WILAYAH KERJA PUSKESMAS WAY HALIM KOTA BANDAR LAMPUNG

Pendahuluan: Proporsi risiko kurang energi kronis pada perempuan usia subur menurun dibanding tahun 2013 , dari 24,2 persen pada perempuan usia subur yang hamil di 2013 menjadi 17,3 persen di 2018. Selain itu untuk perempuan usia subur tidak hamil 20,8 persen di 2013 menurun jadi 14,5 persen pada 2018 (Riskesdas, 2018). Persentase ibu hamil yang mengalami anemia tersebut meningkat dibandingkan hasil Riskesdas tahun 2013 yaitu sebesar 37,1 persen.

Tujuan: Diketahui pengaruh konsumsi ekstrak daun kelor dan madu terhadap peningkatan $\mathrm{Hb}$ ibu hamil di Wilayah Kerja Puskesmas Way Halim Kota Bandar LampungTahun 2019.

Metode: Jenis penelitian ini adalah Kuantitatif. Desain penelitian metode Quasi Eksperimental pendekatan one group pretes-postes one group pretes-postes. Sampel yang digunakan sebanyak 30 responden, teknik sampel purposive sampling Analisa data mengguanakan univariat dan bivariate dengan $t$-tes.

Hasil :Rata-rata hb ibu hamil sesudah diberi ekstra daun kelor dan madu di Wilayah Kerja Puskesmas Way Halim Kota Bandar LampungTahun 2019 dengan Mean 11,100 Min 9,5 Max 12,2 dan standar deviasi 0,5657 dan standar eror 0,1033, dan setelah diberi intervensi Mean 11,100 Min 9,5 Max 12,2 dan standar deviasi 0,5657 dan standar eror 0,1033 . Hasil uji statistik didapatkan nilai $P$ value $=0.000$

Kesimpulan : Artinya terdapat pengaruh konsumsi ekstrak daun kelor dan madu terhadap peningkatan Hb Ibu Hamil Di Wilayah Kerja Puskesmas Way Halim Kota Bandar LampungTahun 2019. Saran ibu hamil agar selalu mengonsusmsi ekstrak daun kelor dengan cara mengonsumsi kapsul yang berisis bubuk daun kelor dengan dosis $2 \times 2$ kapsul / hari (perkapsul berisi $500 \mathrm{mg}$ bubuk daun kelor) selama 15 hari., untuk persiapan menjelang persalinan, karena saat bersalin ibu mememerlukan tenaga, dan cukup banyak darah setelah bersalin.

Kata Kunci: Ekstrak Daun kelor dan Madu, Hemoglobin, Ibu hamil

\section{PENDAHULUAN \\ LATAR BELAKANG}

Kadar $\mathrm{Hb}$ ialah ukuran pigmen respiratorik dalam butiran-butiran darah merah, jumlah $\mathrm{Hb}$ dalam darah normal adalah kira-kira 15 gram setiap $100 \mathrm{ml}$ darah dan jumlah ini biasanya disebut 100 persen. WHO telah menetapkan batas kadar $\mathrm{Hb}$ normal berdasarkan umur dan jenis kelamin, anak 6 bulan sampai 6 tahun batas nilai $\mathrm{Hb} 11,0 \mathrm{gr}$, anak 6 tahun sampai 14 tahun batas nilai $\mathrm{Hb} 12,0$ gr, pria dewasa batas nilai $\mathrm{Hb} 13,0 \mathrm{gr}$, ibu hamil batas nilai $\mathrm{Hb}$ $11,0 \mathrm{gr}$, wanita dewasa batas nilai
$\mathrm{Hb} 12,0$ gr (WHO dalam Arisman, 2010). Maka dapat dikatakan bahwa $\mathrm{Hb}$ ibu hamil yang rendah atau kurang dari 11 gr masuk dalam kategori anemia.

Sebagian besar perempuan mengalami anemia selama kehamilan, baik di Negara maju maupun Negara berekembang. Badan Kesehatab Dunia atau World Health Organization (WHO) memperkirakan bahwa 35-75\% ibu hamil diNegara berekembang dan 18\% ibu hamil di Negara maju mengalami anemia. Namun, banyak diantara mereka yang telah mengalami menderita anemia sat konsepsi, dengan perkiraan 
prevelensi sebesar $43 \%$ pada perempuan yang tidak hamil di Negara berkembang dan $12 \%$ di Negara yang lebih maju (Prawirohardjo, 2016)

Hampir separuh atau sebanyak 48,9 persen ibu hamil di Indonesia menderita anemia atau kekurangan darah, demikian hasil Riset Kesehatan Dasar (Riskesdas) tahun 2018. Berdasarkan data Riskesdas 2018 yang dirilis di Jakarta, Jumat $(2 / 11 / 2018)$, persentase ibu hamil yang mengalami anemia tersebut meningkat dibandingkan hasil Riskesdas tahun 2013 yaitu sebesar 37,1 persen (Riskesdas, 2018).

Dari data tahun 2018, jumlah ibu hamil yang mengalami anemia paling banyak pada usia 15-24 tahun sebesar 84,6 persen, usia 25 34 tahun sebesar 33,7 persen, usia 35-44 tahun sebesar 33,6 persen, dan usia 45-54 tahun sebesar 24 persen. Sementara data perempuan usia subur yang mengalami kekurangan energi kronis justru menunjukkan tren positif dibanding tahun-tahun sebelumnya. Proporsi risiko kurang energi kronis pada perempuan usia subur menurun dibanding tahun 2013, dari 24,2 persen pada perempuan usia subur yang hamil di 2013 menjadi 17,3 persen di 2018. Selain itu untuk perempuan usia subur tidak hamil 20,8 persen di 2013 menurun jadi 14,5 persen pada 2018 (Riskesdas, 2018).

Data kejadian anemia pada ibu hamil di Kota Bandar lampung, dengan dengan melihat 3 puskesmas yang memiliki angka kejadian hipertensi tertinggi, yaitu Puskesmas Way Halim sebanyak 958 (76,04\%), Puskesmas Beringin Raya sebanyak 375 orang $(84,88 \%)$ dan Puskesmas Sukamaju sebanyak 287 orang (72,45\%) (Dinkes Provinsi Bandar Lampung, 2018).

Anemia defisiensi besi merupakan salah satu manifestasi anemia pada ibu, anak dan masalah gizi. Prevalensi anemia di tingkat nasional masih cukup tinggi. Pada ibu hamil 50,9\%, ibu nifas $45,1 \%$, remaja putri usia 10-14 tahun $57,1 \%$ dan pada wanita usia subur (WUS) usia 17-45 tahun sebesar 39,5\% (Kemenkes RI, 2012).

Faktor-faktor yang dapat menimbulkan anemia defisiensi besi antara lain kurangnya asupan zat besi yang dipengaruhi pola konsumsi masyarakat, peningkatan kebutuhan tubuh akibat infeksi, penyakit kronis, hamil, menstruasi dan faktor sosial ekonomi (Isniati, 2007; Paendong, 2016). Anemia defisiensi besi dapat menyebabkan gangguan respon imun yang rentan terhadap infeksi, gangguan gastrointestinal, gangguan kemampuan kerja fisik, gangguan kognitif dan tingkah laku. Selain gangguan perkembangan, defisiensi besi juga dapat menyebabkan kelainan neurologis (Yager \& Hartfield, 2002; Paendong, 2016).

Konsumsi daun kelor (Moringa oleifera) merupakan salah satu alternatif untuk menanggulangi kasus kekurangan gizi di indonesia. Hasil riset ilmiah modern membuktikan bahwa daun kelor adalah salah satu sumber pangan nabati yang kaya akan kandungan gizi. Kandungan unsur gizi dalam daun kelor adalah 7 kali vitamin $C$ dalam buah jeruk , 4 kali vitamin A dalam wortel, 4 kali kalsium dalam susu , 3 kali kalium dalam pisang, 3 kali zat besi dalam bayam dan 2 kali protein yang terdapat dalam yoghurt atau protein dalam sebutir telur (Aisha., Lowell; Sylvie, 2013).

Daun kelor memiliki potensi yang sangat baik untuk melengkapi kandungan nutrisi dalam tubuh, meningkatkan energi dan ketahanan tubuhnya serta untuk mengatasi keluhan akibat 
kekurangan mineral seperti kekurangan zat besi yang mengakibatkan anemia (Dhakar et al., 2011; Sylvie, 2013). Pada daun kelor yang dikeringkan memiliki kadar protein, zat besi, vitamin A dan vitamin $C$ yang tinggi, sehingga sangat efektif untuk mengobati anemia defisiensi besi. Selain itu, daun ini tidak mengandung zat berbahaya sehingga tidak memiliki efek samping. Selama ini tidak pernah ditemukan kasus atau keracunan akibat mengkonsumsi daun kelor (Fahey, 2005; Sylvie, 2013).

Konsumsi daun kelor (Moringa oleifera) merupakan salah satu alternatif untuk menanggulangi kasus kekurangan gizi di indonesia. Hasil riset ilmiah modern membuktikan bahwa daun kelor adalah salah satu sumber pangan nabati yang kaya akan kandungan gizi. Hasil analisa Balbir S. Mathur menunjukkan bahwa daun kelor memiliki kandungan gizi yang sangat penting untuk menjaga berbagai macam penyakit. (Balbir, 201; Sylvie, 2013)

Selain konsumsi ekstrak daun kelor meningkatkan hb juga dapat dibantu dengan konsumsi madu, karena dalam madu terdapat kandungan mineral diantaranya; belerang (S), kalsium (Ca), tembaga $(\mathrm{Cu})$, mangan $(\mathrm{Mn})$, besi $(\mathrm{Fe})$, fosfor $(\mathrm{P})$, klor $(\mathrm{Cl})$, kalium $(\mathrm{K})$, magnesium $(\mathrm{Mg})$, iodium $(\mathrm{I})$, seng $(\mathrm{Zn})$, silikon $(\mathrm{Si})$, natrium (Na), molibdenum (Mo) dan aluminium (Al) sedangkan potasium merupakan mineral utama pada madu, disamping itu madu pun mengandung vitamin diantaranya vitamin $E$, vitamin $C$ serta vitamin B1, B6, dan asam folat (Nur, 2017). Madu mengandung zat besi (Fe), yang merupakan mikromineral yang sangat penting di dalam tubuh karena dapat berfungsi sebagai pembentuk sel darah merah. Kandungan zat besi dapat mensintesis pembentukan heme yang dapat memacu kadar Hemoglobin.22 Kandungan lain madu yang berperan penting dalam melarutkan zat besi yaitu vitamin C (Nur, 2017).

Zat besi dengan vitamin $\mathrm{C}$ membentuk askorbat besi kompleks yang larut dan mudah untuk diserap oleh organ-organ pada tubuh manusia. Pengubahan zat besi non-heme dalam bentuk senyawa etabolis Ferri menjadi Ferro akan semakin besar bila pH di dalam lambung semakin asam. Vitamin C dapat menambah keasaman sehingga membantu meningkatkan penyerapan zat besi sebanyak 30\%.6 Selain itu, adanya asam folat yang juga penting untuk pembentukan sel baru, sehingga dapat mempengaruhi $\mathrm{Fe}$ dalam darah dan diharapkan terjadinya peningkatan hemoglobin (Nur, 2017).

Penelitian oleh Sylvie (2013) dengan judul "efektivitas suplementasi bubuk daun kelor (moringa oleifera) terhadap peningkatan kadar hemoglobin pada ibu hamil yang menderita anemia" Hasil uji hipotesis komparatif dengan uji Wilcoxon antara kadar $\mathrm{Hb}$ sebelum dan sesudah perlakuan diperoleh nilai significancy $0,000(p<0,05)$, sehingga dapat disimpulkan bahwa terdapat perbedaan yang bermakna kadar $\mathrm{Hb}$ antara sebelum perlakuan dan sesudah perlakuan.

Dari pemaparan diatas, peneliti tertarik melakukan penelitian dengan judul "Pengaruh Konsumsi Ekstrak Daun Kelor Dan Madu Terhadap Peningkatan $\mathrm{Hb}$ Ibu Hamil di Wilayah Kerja Puskesmas Way Halim Kota Bandar LampungTahun 2019”. 


\section{METODE PENELITIAN}

Jenis penelitian ini merupakan jenis penelitian kuantitatif. Jenis penelitian kuantitatif adalah penelitian dengan memperoleh data yang berbentuk angka atau kualitatif yang diangkakan (Notoadmodjo, 2018). Rancangan dalam penelitian ini menggunakan desainQuasi Eksperimental dengan pendekatan one group pretest - posttest design.
Penggunaan sampel ukuran sekitar $10 \%$ dari populasi dianjurkan. Sementara Dempsey (2002) menyatakan bahwa 15 sampai 25 subyek per kelompok, sedangka untuk penelitian dengan metode quasi eksperimen sampel minimal yang digunakan sebanyak 30 responden.

HASIL

Analisa Univariat

Tabel 1.

Rata-Rata Hb Ibu Hamil Sebelum Diberi Ekstra Daun Kelor Dan Madu Di Wilayah Kerja Puskesmas Way Halim Kota Bandar Lampung

\begin{tabular}{|c|c|c|c|c|c|c|}
\hline Variabel & $\mathbf{N}$ & Mean & $\begin{array}{l}\text { Min- } \\
\text { Max }\end{array}$ & $\begin{array}{l}\text { Std. } \\
\text { Dev }\end{array}$ & $\begin{array}{l}\text { Std, } \\
\text { Eror }\end{array}$ & $\mathrm{Cl}-95 \%$ \\
\hline $\begin{array}{l}\text { Kadar Hb } \\
\text { sebelum } \\
\text { intervensi }\end{array}$ & 30 & 10,167 & $\begin{array}{l}9.0- \\
11.5\end{array}$ & 0,6759 & 0,1234 & $\begin{array}{c}9,914- \\
10,419\end{array}$ \\
\hline
\end{tabular}

Dari tabel diatas dapat diketahui bahwa rata-rata hb ibu hamil sebelum diberi ekstra daun kelor dan madu di Wilayah Kerja Puskesmas Way Halim Kota Bandar
LampungTahun 2019 dengan Mean 10,167 Min 9,0 Max 11,5 dan standar deviasi 0,6759 dan standar eror 0.1234 .

Tabel 2.

Rata-Rata Hb Ibu Hamil Sesudah Diberi Ekstra Daun Kelor Dan Madu Di Wilayah Kerja Puskesmas Way Halim Kota Bandar LampungTahun 2019

\begin{tabular}{|c|c|c|c|c|c|c|}
\hline Variabel & $\mathbf{N}$ & Mean & $\begin{array}{l}\text { Min- } \\
\text { Max }\end{array}$ & $\begin{array}{l}\text { Std. } \\
\text { Dev }\end{array}$ & $\begin{array}{l}\text { Std, } \\
\text { Eror }\end{array}$ & $\mathrm{Cl}-95 \%$ \\
\hline $\begin{array}{l}\text { Kadar Hb } \\
\text { sesudah } \\
\text { intervensi }\end{array}$ & 30 & 11,100 & $\begin{array}{l}9,5- \\
12,2\end{array}$ & 0,5657 & 0,1033 & $\begin{array}{c}10,889- \\
11,311\end{array}$ \\
\hline
\end{tabular}

Dari tabel diatas dapat diketahui bahwa rata-rata hb ibu hamil sesudah diberi ekstra daun kelor dan madu di Wilayah Kerja Puskesmas Way Halim Kota Bandar
LampungTahun 2019 dengan Mean 11,100 Min 9,5 Max 12,2 dan standar deviasi 0,5657 dan standar eror 0,1033 . 


\section{Analisis Bivariat}

Tabel 3.

Pengaruh Konsumsi Ekstrak Daun Kelor Dan Madu Terhadap Peningkatan Hb Ibu Hamil Di Wilayah Kerja Puskesmas Way Halim Kota Bandar Lampung

\begin{tabular}{ccccccc}
\hline Variabel & $\mathbf{N}$ & Mean & Std. Dev & SE & P -Value & Cl-95\% \\
\hline Pretest & 30 & 10,167 & 0,6759 & 0,1234 & & $-1.22-0,64$ \\
\cline { 1 - 5 } Posttest & 30 & 11,100 & 0,5657 & 0,1033 & 0.001 & \\
\hline
\end{tabular}

Dari tabel terlihat bahwa ratarata kadar $\mathrm{Hb}$ sebelum dan sesudah diberi ekstrak daun kelor dan madu dengan 30 responden dengan Mean10,167 standar deviasi 0,6759 dan standar eror 0,1234 pada pengukuran ke dua didapat 30 responden dengan kadar $\mathrm{Hb}$ sesudah diberi ektrak daun kelor dan madu

\section{Pembahasan}

\section{Analisis Univariat}

1. Rata-Rata Hb lbu Hamil Sebelum Diberi Ekstra Daun Kelor Dan Madu Di Wilayah Kerja Puskesmas Way Halim Kota Bandar LampungTahun 2019

Dari tabel 4.2 diatas dapat diketahui bahwa rata-rata hb ibu hamil sebelum diberi ekstra daun kelor dan madu di Wilayah Kerja Puskesmas Way Halim Kota Bandar LampungTahun 2019 dengan Mean 10,167 Min 9,0 Max 11,5 dan standar deviasi 0,6759 dan standar eror 0.1234 .

Sejalan dengan teori Bakta (2017) Kandungan $\mathrm{Hb}$ yang rendah dengan demikian mengindekasikan anemia, bergantung pada metode yang digunakan, nilai $\mathrm{Hb}$ menjadi akurat sampai 2-3\%. Gejala anemia berupa lemah, kurang nafsu makan, kurang energi, konsenstrasi menurun, sakit kepala, mudah trinfeksi penyakit, mata kunangkunang, selain itu kelopak mata,bibir, dan kuku tampak dengan Mean 11,100, standar deviasi 0.5657 dan standar eror 0,1033. Hasil uji statistik didapatkan nilai $P$ value $=0.000$ yang artinya terdapat pengaruh konsumsi ekstrak daun kelor dan madu terhadap peningkatan $\mathrm{Hb}$ Ibu Hamil Di Wilayah Kerja Puskesmas Way Halim Kota Bandar LampungTahun 2019.

pucat. Penanggulangan ibu hamil dapat dilakukan dengan cara pemberian tablet besi serta peningkatan kualitas makanan sehari-hari.

Sejalan dengan penelitian yang dilakukan oleh Yulianti (2016) "Pengaruh Ekstrak Daun Kelor Terhadap Peningkatan Kadar Hemoglobin Pada Remaja Putri Di Smu Muhammadiyah Kupang". Sampel penlitian sebanyak 60 , 30 kelompok perlakuan dan 30 kelompok control yang ditetapkan secara purposif. Pengumpulan data dilakukan melalui observasi dan pemeriksaan laboratorium kadar hemoglobin dengan alat ukur metode cyanmet fotometer.

Menurut peneliti Kandungan $\mathrm{Hb}$ yang rendah dapat mengindekasikan anemia, bergantung pada metode yang digunakan, nilai $\mathrm{Hb}$ menjadi akurat sampai 23\%. Gejala anemia berupa lemah, kurang nafsu makan, kurang energi, konsenstrasi menurun, sakit kepala, mudah trinfeksi penyakit, mata 
kunang-kunang, selain itu kelopak mata,bibir, dan kuku tampak pucat. Penanggulangan ibu hamil dapat dilakukan dengan cara pemberian tablet besi serta peningkatan kualitas makanan sehari-hari.

Pada hasil penelitian ini, nilai kadar $\mathrm{Hb}$ terendah sebelum di beri perlakuan adalah 10,167 gr/dl yang masuk ke dalam anemia ringan, hal tersebut mempengaruhi kegiatan ibu hamil dalam menjalankan aktivitas rumah tangga, seperti masak, dan membereskan rumah.

2. Rata-Rata Hb lbu Hamil Sesudah Diberi Ekstra Daun Kelor Dan Madu Di Wilayah Kerja Puskesmas Way Halim Kota Bandar LampungTahun 2019

Dari tabel 4.3 diatas dapat diketahui bahwa ratarata hb ibu hamil sesudah diberi ekstra daun kelor dan madu di Wilayah Kerja Puskesmas Way Halim Kota Bandar LampungTahun 2019 dengan Mean 11,100 Min 9,5 Max 12,2 dan standar deviasi 0,5657 dan standar eror 0,1033 .

Sejalan dengan teori Manuaba (2010) dikatakan anemia bila kadar $\mathrm{Hb}$ pada wanita hamil trimester $I<11$ $\mathrm{gr} / \mathrm{dl}$, trimester $\mathrm{Il}<10,5 \mathrm{gr} / \mathrm{dl}$ dan trimester III < $10 \mathrm{gr} / \mathrm{dl}$. Kadar $\mathrm{Hb}$ ibu hamil terjadi jika produksi sel darah merah meningkat, nilai normal haemoglobin (12 sampai $16 \mathrm{gr} / \%)$ dan nilai normal hematokrit $\quad(37 \%$ sampai $47 \%$ ) menurun secara menyolok. Penurunan lebih jelas terlihat selama trimester kedua, saat terjadi ekspansi volume darah yang cepat. Apabila nilai hematokrit turun sampai $35 \%$ atau lebih, wanita dalam keadaan anemia (Benson, 2009).

Sejalan dengan penelitian yang dilakukan oleh Sylvie (2013) dengan judul "efektivitas suplementasi bubuk daun kelor (moringa oleifera) terhadap peningkatan kadar hemoglobin pada ibu hamil yang menderita anemia" Hasil uji hipotesis komparatif dengan uji Wilcoxon antara kadar $\mathrm{Hb}$ sebelum dan sesudah perlakuan diperoleh nilai significancy $0,000(p<0,05)$, sehingga dapat disimpulkan bahwa terdapat perbedaan yang bermakna kadar $\mathrm{Hb}$ antara sebelum perlakuan dan sesudah perlakuan.

Pada penelitian ini didapat nilai kadar $\mathrm{Hb}$ setelah diperlakuan dengan menggunakan ekstrak daun kelor dan madu selama 15 hari, mengalami peningkatan 9,5$12,2 \mathrm{gr} / \mathrm{dl}$, yang artinya ibu berhasil melakukan terapi yang diajarkan oleh peneliti dan sesuai dengan standar prosedur, selain itu responden juga mengkonsumsi makanan perhari yang mengandung zat besi seperti, bayam, daun singkong, ikan asin, jenis olahan ikan segar, dan juga konsumsi ekstrak daun kelor. Sedangkan hasil penelitian ini terdapat beberapa orang yang masih mengalami anemia ringan, disebabkan oleh waktu uji coba hanya 15 hari sehingga memerlukan waktu yang lebih lama. 
Menurut

peneliti, peningktan kadar $\mathrm{Hb}$ pada ibu hamil sangat dipengaruhi oleh asupan makanan juga asupan suplemen yang dapat meningkatkan kadar $\mathrm{Hb}$.

Analisa Bivariat

1. Pengaruh Konsumsi Ekstrak Daun Kelor Dan Madu Terhadap Peningkatan $\mathrm{Hb}$ lbu Hamil Di Wilayah Kerja Puskesmas Way Halim Kota Bandar LampungTahun 2019

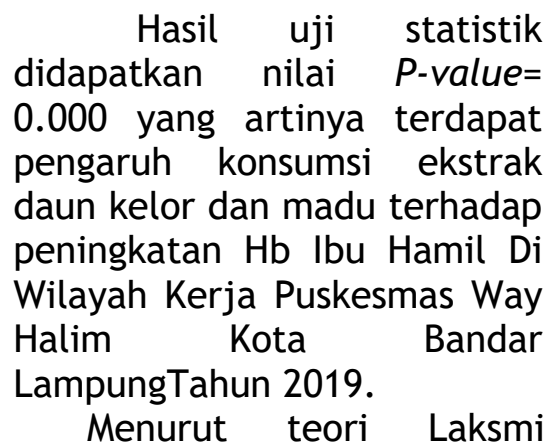
Sejalan dengan penelitian yang dilakukan oleh Yulianti (2016) "Pengaruh Ekstrak Daun Kelor Terhadap Peningkatan Kadar Hemoglobin Pada Remaja Putri Di Smu Muhammadiyah Kupang”. Hasil penelitian menunjukkan bahwa terdapat nilai $p=0.000<a=0.05$. dengan demikkian terdapat perbedaan kadar hemoglobin responden yang significant pada kelompok perlakuan dengan nilai $p=0,000$ $(p<0,05)$, sedangkan pada kelompok kontrol tidak signifikan antara ekstrak daun kelor dan peningkatan kadar hemoglobin pada remaja putri

Daun kelor juga mengandung semua unsur asam amino yang penting (essensial). Berbagai nutrisi ini merupakan suatu sumber yang luar biasa dari tumbuhan. Kecuali vitamin C, semua kandungan gizi yang terdapat dalam daun kelor segar akan mengalami peningkatan konsentrasinya) apabila dikonsumsi setelah dikeringkan dan dilumatkan dalam bentuk serbuk atau tepung. Satu sendok makan bubuk daun kelor berisi $14 \%$ protein, kalsium, zat besi dan provitamin A . Enam sendok makan bubuk daun kelor dapat memenuhi kebutuhan harian kalsium dan zat besi bagi hamil dan menyusui (Lowell, 2004; Balbir, 2011; Deptan, 2012).

Madu mengandung zat besi (Fe), yang merupakan mikromineral yang sangat penting di dalam tubuh karena dapat berfungsi sebagai pembentuk sel darah merah. Kandungan zat besi dapat mensintesis pembentukan heme yang dapat memacu kadar Hemoglobin. Kandungan lain madu yang berperan penting dalam melarutkan zat besi yaitu vitamin C (Zen, 2013; Nur, 2013)

Sejalan dengan penelitian yang dilakukan oleh Sylvie (2013) dengan judul "efektivitas suplementasi bubuk daun kelor (moringa oleifera) terhadap peningkatan kadar hemoglobin pada ibu hamil yang menderita anemia" Hasil uji hipotesis komparatif dengan uji Wilcoxon antara kadar $\mathrm{Hb}$ sebelum dan sesudah perlakuan diperoleh nilai significancy $0,000(p<0,05)$, sehingga dapat disimpulkan bahwa terdapat perbedaan yang bermakna kadar $\mathrm{Hb}$ antara sebelum perlakuan dan sesudah perlakuan.

Menurut peneliti anemia pada ibu hamil dapat dikurangi dengan memberikan asupan 
nutrisi yang cukup dan baik, seperti mengkonsumsi makanan yang banyak mengandung vitamin $\mathrm{C}$ dan ekstrak daun kelor, dalam 1 kapsul seberat $35 \mathrm{mg}$ jika dikonsumsi 2 tablet sehari, maka akan terpenuhi kebutuhan Fe sebesar 56,4 mg, yang dibantu dengan zat besi pada kandungan makanan yang lainnya. Pemberian dilakukan selama 15 hari.

Pada penelitian ini 3 orang tidak mengalami peningkatan kadar $\mathrm{Hb}$ dengan nilai antara 9,5-11 gr/dl dari sebelum dilakuakan terapi ekstrak daun kelor dan madu, hal ini dapat disebabkan karena pola makan serta istirahat ibu, ibu yang kurang tidur dan banyak mengkonsumsi minuman seperti kopi dan teh, akan mempengaruhi penyerapan zat besi baik pada makanan dan tablet ekstrak daun kelor, Peningkatan $\mathrm{Hb}$ pada nilai 11,5 mengalami peningkatan menjadi 12,2 yang artinya terdapat peningkatan $\mathrm{Hb}$ yang signifikan, dikarenakan pola makan, serta ketepatan dalam konsumsi tablet $\mathrm{Fe}$ yang dibantu dengan daun kelor dan madu, sehingga membantu penyerapan zat besi yang ada pada makanan atau obat.

\section{KESIMPULAN DAN SARAN}

Kesimpulan

Penelitian dengan judul "Pengaruh Konsumsi Ekstrak Daun Kelor Dan Madu Terhadap Peningkatan $\mathrm{Hb}$ Ibu Hamil Di Wilayah Kerja Puskesmas Way Halim Kota Bandar LampungTahun 2019" dapat ditarik kesimpulan sebagai berikut:
1. Rata-rata hb ibu hamil sesudah diberi ekstra daun kelor dan madu di Wilayah Kerja Puskesmas Way Halim Kota Bandar LampungTahun 2019 dengan Mean 11,100 Min 9,5 Max 12,2 dan standar deviasi 0,5657 dan standar eror 0,1033

2. Rata-rata hb ibu hamil sesudah diberi ekstra daun kelor dan madu di Wilayah Kerja Puskesmas Way Halim Kota Bandar LampungTahun 2019 dengan Mean 11,100 Min 9,5 Max 12,2 dan standar deviasi 0,5657 dan standar eror 0,1033 .

3. Hasil uji statistik didapatkan nilai $P$-value $=0.000$ yang artinya terdapat pengaruh konsumsi ekstrak daun kelor dan madu terhadap peningkatan $\mathrm{Hb}$ Ibu Hamil Di Wilayah Kerja Puskesmas Way Halim Kota Bandar LampungTahun 2019.

\section{Saran}

1. Bagi Ibu Hamil

Diharapkan bagi ibu hamil agar selalu mengonsusmsi ekstrak daun kelor dengan cara mengonsumsi kapsul yang berisis bubuk daun kelor dengan dosis $2 \times 2$ kapsul / hari (perkapsul berisi $500 \mathrm{mg}$ bubuk daun kelor) selama 15 hari, untuk persiapan menjelang persalinan, karena saat bersalin ibu mememerlukan tenaga, dan cukup banyak darah setelah bersalin.

2. Bagi Puskesmas Way Halim Diharapkan bagi puskesmas dan tenaga kesehatan lainnya, agar rutin memberikan penyuluhan berupa leaflet kepada ibu hamil, tentang pentingnya mengkonsumsi makanan tambahan seperti, daging, dan sayuran yang 
mengandung zat besi serta ekstrak daun kelor yang kaya akan vitamin $c$ yang membantu penyerapan zat bezi baik pada makanan

3. Bagi Peneliti Selanjutnya Hasil penelitian ini diharapkan dapat digunakan sebagai bahan referensi dalam melakukan penelitian selanjutnya, dan diharapkan juga kepada peneliti selanjutnya untuk dapat mengkaji status gizi ibu selama kehamilan dan mengganti dengan intervensi lainnya yang berkaitan dengan pengaruh pemberian suatu intervensi terhadap kenaikan $\mathrm{Hb}$ pada ibu hamil.

\section{DAFTAR PUSTAKA}

Arikunto. (2010). Prosedur Penelitian Suatu Pendekatan Praktik.Jakarta: Rineka Cipta.

Arisman. (2010). Gizi dalam Daur Kehidupan: Buku Ajar Ilmu Gizi. Jakarta: EGC.

Bakta. (2017). Hematologi Klinik Ringkas. Jakarta: EGC.

Helen, Va. (2007). Buku Ajar Asuhan Kebidanan Buku Kedokteran. Jakarta: EGC.

Hermansyah., Hadju., Bahar. (2014). Ekstrak Daun Kelor Terhadap Peningkatan Asupan Dan Berat Badan Ibu Hamil Pekerja Sektor Informal. Makasar: Fakultas Kesehatan Masyarakat, Universitas Hasanuddin.

Ibrahimiyah. (2014). Pengaruh Pemberian Ekstrak Daun Kelor (Moringa Oleifera) Terhadap Kadar Hemoglobin Pada Tikus
Strain Wistar Yang Diinduksi Aluminium Klorida. Malang: Fakultas Kedokteran. Universitas Muhammadiyah.

Janah, Nurul. (2012). Buku Ajar Asuhan Kebidanan Kehamilan. Yogyakarta: CV Andi Ofset.

Kamil. (2015). Pengaruh Pemberian Madu Randu Terhadap Peningkatan Status Gizi PadaPetugas Kebersihan Di Universitas Islam Bandung. Fakultas Kedokteran, Universitas Islam: Bandung.

Kemenkes. (2014). Profil Sehat Indonesia. Jakarta .

Manuaba, IBG. (2010). Ilmu Kebidanan, Penyakit Kandungan dan Keluarga Berencana Untuk Pendidikan Bidan. Jakarta: EGC.

Notoatmojo, S. (2018). Metodelogi Penelitian Kesehatan Rineka Cipta: Jakarta.

Renny dkk. (2010). Madu Temulawak Meningkatkan Berat Badan Anak Usia Toddler. Fakultas Keperawatan Universitas Airlangga.

Rukiyah, Ai, Yeyeh. (2015) Asuhan Kebidanan Patologi Kebidanan 4 Edisi Revisi. Jakarta: Trans Infomedia.

Sugiyono. (2012). Statistik untuk Penelitian. Bandung: CV. Alfabeta.

Sulistyawati, Ari. (2009). Asuhan Kebidanan Pada Masa Kehamilan. Jakarta: Salemba Medika. 
Supariyasa, I D. (2012). Penilaian Status Gizi. Jakarta: Penerbit Buku. Kedokteran EGC.

Sylvie, S. (2013). Efektivitas Suplementasi Bubuk Daun Kelor (MoringaOleifera) Terhadap Peningkatan Kadar Hemoglobin Padalbu Hamil Yang Menderita Anemia. Universitas Manado: Jurusan Gizi Poltekkes Kemenkes Manado.

Waryana. (2010) Gizi Reproduksi. Yogyakarta: Pustaka Rahima.

Wiguna, Imam. (2018). Pasar \& Kjasiat Kelor. PT. Trubus Sukatani: Depok.

Wiknjosastro, H. (2016) Ilmu Kebidanan. Jakarta: Yayasan Bina Pustaka Sarwono Prawirohardjo.

Yuni, Erlina Natalia. (2015). Kelainan Darah. Yogyakarta: Nuha Medika. 